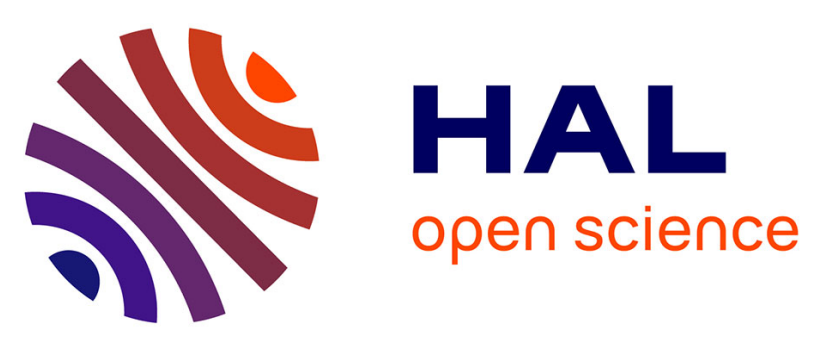

\title{
Clicked Bifunctional Dendrimeric and Cyclopeptidic Addressable Redox Scaffolds for the Functionalization of Carbon Nanotubes with Redox Molecules and Enzymes
} Solène Gentil, Carlo Pifferi, Pierre Rousselot-Pailley, Thierry Tron, Olivier Renaudet, Alan Le Goff

\section{To cite this version:}

Solène Gentil, Carlo Pifferi, Pierre Rousselot-Pailley, Thierry Tron, Olivier Renaudet, et al.. Clicked Bifunctional Dendrimeric and Cyclopeptidic Addressable Redox Scaffolds for the Functionalization of Carbon Nanotubes with Redox Molecules and Enzymes. Langmuir, 2021, 37 (3), pp.1001-1011. 10.1021/acs.langmuir.0c02095 . hal-03132807

\section{HAL Id: hal-03132807 \\ https://hal.science/hal-03132807}

Submitted on 12 Oct 2021

HAL is a multi-disciplinary open access archive for the deposit and dissemination of scientific research documents, whether they are published or not. The documents may come from teaching and research institutions in France or abroad, or from public or private research centers.
L'archive ouverte pluridisciplinaire HAL, est destinée au dépôt et à la diffusion de documents scientifiques de niveau recherche, publiés ou non, émanant des établissements d'enseignement et de recherche français ou étrangers, des laboratoires publics ou privés. 


\title{
Clicked bifunctional dendrimeric and cyclopeptidic
}

\author{
addressable redox scaffolds for the functionalization
}

of carbon nanotubes with redox molecules and

enzymes

Solène Gentil, Carlo Pifferi, Pierre Rousselot-Pailley, Thierry Tron, Olivier Renaudet, Alan Le Goff

To cite this version

Gentil, Solène, Carlo Pifferi, Pierre Rousselot-Pailley, Thierry Tron, Olivier Renaudet, et Alan Le Goff. « Clicked Bifunctional Dendrimeric and Cyclopeptidic Addressable Redox Scaffolds for the Functionalization of Carbon Nanotubes with Redox Molecules and Enzymes ». Langmuir 37, $\mathrm{n}^{\circ} 3$ (26 janvier 2021): 1001-11. https://doi.org/10.1021/acs.langmuir.0c02095. hal-03132807 


\title{
Clicked bifunctional dendrimeric and cyclopeptidic
}

\author{
addressable redox scaffolds for the functionalization
}

of carbon nanotubes with redox molecules and

\section{enzymes}

Solène Gentil, ${ }^{a, b}$ Carlo Pifferi ${ }^{a}$, Pierre Rousselot-Pailley, ${ }^{c}$ Thierry Tron,${ }^{c *}$ Olivier Renaudet, ${ }^{a *}$ Alan Le Goff ${ }^{a *}$

[a] Univ. Grenoble Alpes, CNRS, DCM, 38000 Grenoble

[b] Univ. Grenoble Alpes, CEA, CNRS, BIG-LCBM, 38000 Grenoble, France

[c] Aix Marseille Université, Centrale Marseille, CNRS, iSm2 UMR 7313,13397 Marseille,

France

KEYWORDS carbon nanotubes, laccases, oxygen reduction, dendrimers, cyclopeptides

SG and CP contributed equally to this work. 
ABSTRACT Carbon nanotube electrodes were modified with ferrocene and laccase using two different click reactions strategies and taking advantage of bifunctional dendrimers and cyclopeptides. Using diazonium functionalization and the efficiency of oxime ligation, the combination of both MWCNT surfaces and modified dendrimers or cyclopeptides allow the access to high surface coverage of ferrocene in the order of $50 \mathrm{nmol} \mathrm{cm}^{-2}$. Furthermore, these electrodes allow the immobilization of mono- and bi-functionalized active multicopper enzymes, laccases, via copper(II)-catalyzed azide-Alkyne cycloaddition. Electrochemical studies underline the high efficiency of the oxime-ligated dendrimers or cyclopeptides for the immobilization of redox entities on surfaces while being detrimental to electron tunneling with enzyme active sites despite controlled orientation.

\section{Introduction}

The efficiency of enzyme-based electrochemical devices such as sensors or fuel cells relies on the optimization of enzyme surface coverage at the surface of the electrode. ${ }^{1-4}$ High catalyst loadings are required in order to maximize current density. This will increase either power output of fuel cells or sensitivity of biosensors. Many strategies have been developed in order to immobilize enzymes via protein entrapment, affinity interactions or covalent chemistry. ${ }^{1,5}$ In particular, electrografting of aryldiazonium salts have proven to be an efficient means of electrode modification by redox enzymes ${ }^{1}$ or bioinspired redox catalysts. ${ }^{6,7}$ Covalent attachment of aryl radicals can be performed on many type of surfaces such as metals, carbon, polymers or even insulating materials. ${ }^{8-10}$ Furthermore, the introduction of a functional group in the para position of the aryldiazonium ring can be done via organic synthesis. These groups can be chosen to interact 
with enzymes, such as laccases, via non-covalent interactions or covalent linkages. Laccases are multicopper enzymes, extensively studied for their ability to oxidize phenolic substrates while concomitantly being able to reduce oxygen into water. A type 1 (T1) mononuclear copper centre is responsible for the binding and oxidation of substrates, while a trinuclear copper centre (TNC) concomitantly reduces oxygen into water. A wide spectrum of oxidizable phenolic substrates, associated with high potential oxygen reduction, for certain types of laccases, make these enzymes at the forefront of the development of numerous types of enzyme-based biotechnological applications. ${ }^{11-14}$ Planar electrodes have been modified by electrografting of aryldiazonium derivatives with pi-extended hydrophobic groups such as anthraquinone, anthracene, or chrysene, ${ }^{15,16}$ This technique has been particularly efficient in the controlled immobilization of laccases. Hence, the strong hydrophobic nature of the aryldiazonium film interacts with the hydrophobic substrate pocket of laccase without affecting the catalytic activity, a strategy further extended to nanostructured electrodes. For instance, amide coupling with amino acid residues has also been employed at planar and nanostructured electrodes for the covalent immobilization of metalloenzymes $^{17-20}$. In this context, bio-orthogonal click chemistry has proved to be highly efficient to achieve the immobilization of biomolecules, which are generally available in low concentration samples. We have recently reported the modification of Multiwalled Carbon Nanotube (MWCNT) electrodes using the copper(II)-catalyzed Azide-Alkyne Cycloaddition "click" chemistry (CuAAC) to efficiently attach alkyne-modified laccases. ${ }^{21}$ Carbon-nanotubebased electrodes show ideal combination of properties such as high electronic conductivity, biocompatibility with enzymes, as well as ease of modification by aryldiazonium chemistry. $1,22,23$

Given their flexible, nano-sized structure, dendrimers have also been employed for electrode modification, allowing for an increased enzyme immobilization. ${ }^{24-27}$ Furthermore, dendrimers and 
other multivalent peptide scaffolds can easily harbor different types of orthogonal functional groups $^{28}$ suitable for enzyme surface grafting as well as carbon nanotube (CNT) functionalization. ${ }^{29,30}$ In this work we exploited multivalent scaffolds 1 and 2 (Figure 1A), each of them harboring both aminooxy and azide functional groups for chemo-selective oxime ligation and $\mathrm{CuAAC}$, respectively, upon reaction with their chemical counterparts (i.e. aldehyde and alkyne, respectively).

Owing to the orthogonality of clickable groups in $\mathbf{1}$ and $\mathbf{2}$, we chose to functionalize Glassy Carbon (GC) and MWCNT electrodes via oxime chemistry (vide infra). ${ }^{31,32}$ This was performed by first investigating the electrografting of 4-(1,3-dithian-2-yl)benzenediazonium (DTBD) on GC and MWCNT electrodes. This technique has been previously employed by K. Kim and colleagues for the immobilization of labelled antibody on GC electrodes. ${ }^{33,34}$ The obtained grafted molecule is a precursor of benzaldehyde, easily deprotected by electrochemical oxidation (Figure 1B).
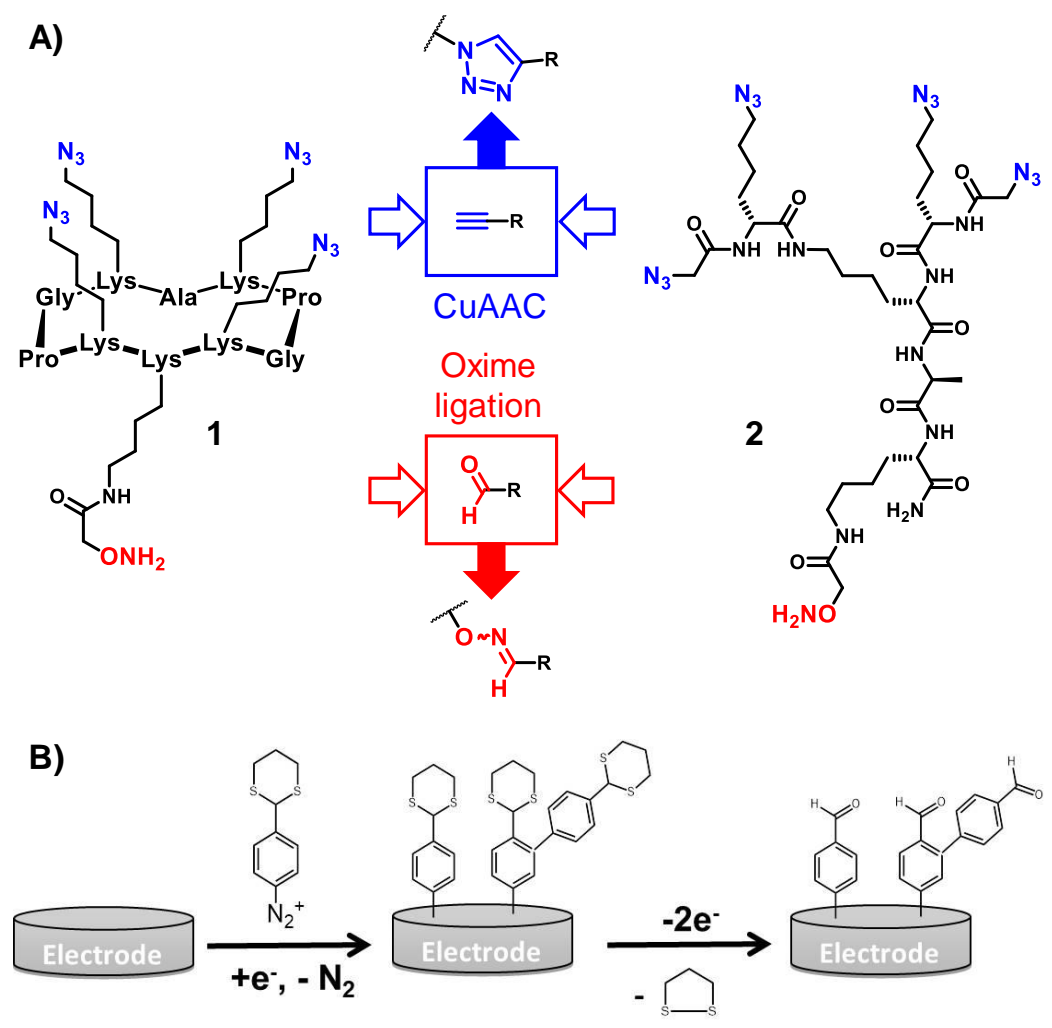
Figure 1. (A) Orthogonally functionalized peptide scaffolds $\mathbf{1}$ and $\mathbf{2}$, grafted with azide and aminooxy groups for CuAAC and oxime ligation, respectively. (B) Electrografting of DTBD followed by electrochemical oxidative deprotection for the installation of aldehyde chemical handles.

Following the immobilization of scaffold $\mathbf{1}$ and $\mathbf{2}$, an alkyne-ferrocene redox probe, as well as an alkyne-modified laccase and one variant, were covalently attached on the immobilized scaffolds via $\mathrm{CuAAC}$. The properties of these functionalized nanostructured electrodes in terms of electron transfer rates, surface coverages and electrocatalytic reduction of $\mathrm{O}_{2}$ on GC and MWCNT electrodes were finally investigated by electrochemical analysis.

\section{Results and discussion}

\section{Aryldiazonium electrografting on $G C$ and $M W C N T$ electrodes}

In the previous work on the electrografting of DTBD, the chloride salt was generated in-situ before electrochemical deposition. ${ }^{33,34}$ Herein, we describe the synthesis of 4-(1,3-dithian-2yl)benzenediazonium tetrafluoroborate obtained by diazotisation of 2-(4-Aminophenyl)-1,3dithiane with $\mathrm{NOBF}_{4}$ in $\mathrm{MeCN}$. After purification, the 4-(1,3-dithian-2-yl)benzenediazoniumon tetrafluoroborate was characterized by ${ }^{1} \mathrm{H}-\mathrm{NMR}$ and infra-red spectroscopy (See the ESI). Its electrochemical characterization was performed in $\mathrm{MeCN}$. Figure 2A displays cyclic voltammograms (CVs) performed in a $2 \mathrm{mmol} \mathrm{L}^{-1}$ solution of DTBD tetrafluoroborate on a GC electrode. 

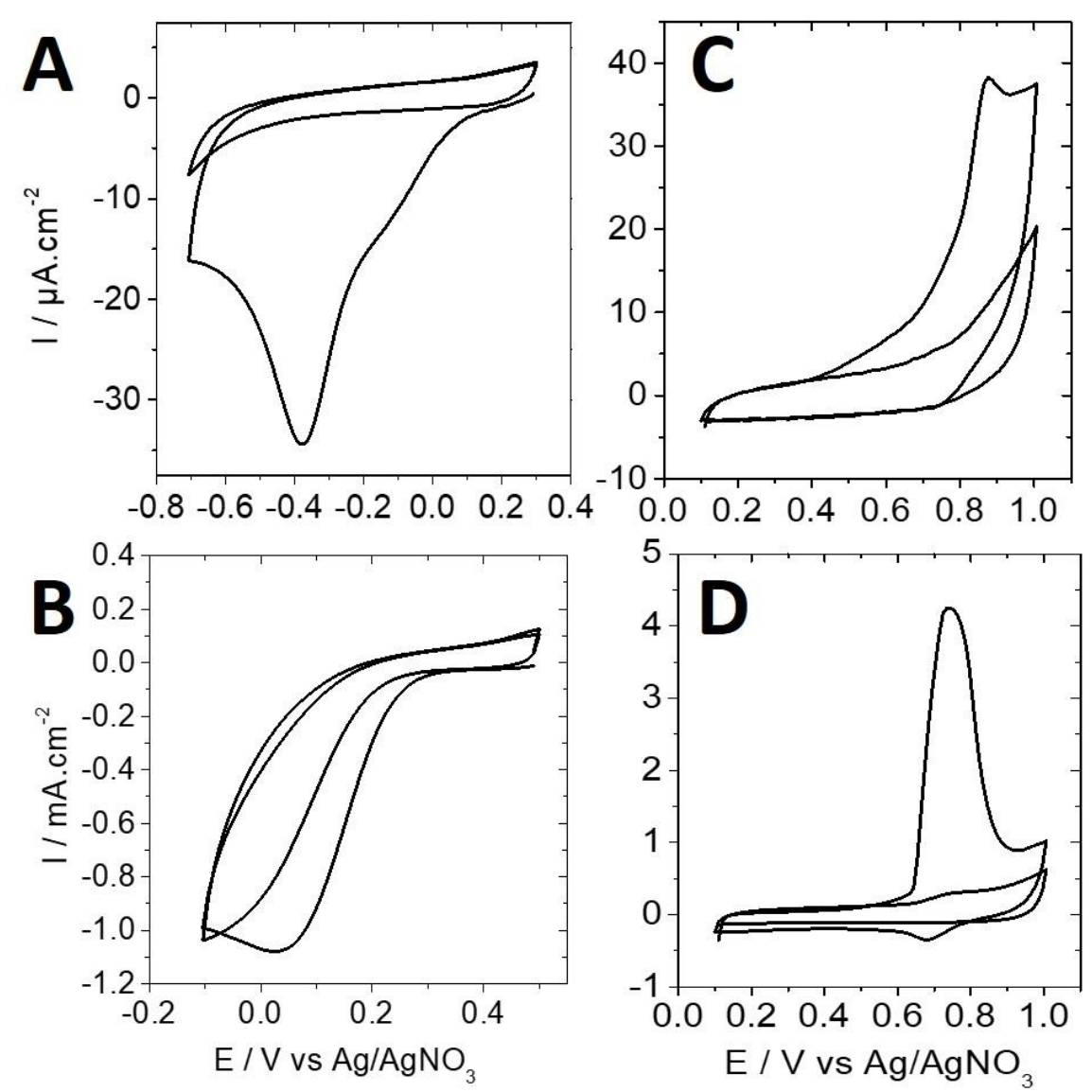

Figure 2. Cyclic voltammetry (CV) of a $2 \mathrm{mmol} \mathrm{L}^{-1}$ solution of 4-(1,3-dithian-2yl)benzenediazonium tetrafluoroborate in $\operatorname{MeCN}-\mathrm{TBAP}\left(0.1 \mathrm{~mol} \mathrm{~L}^{-1}\right)$ at a (A) $\mathrm{GC}$ and (B) MWCNT electrode (2 scans, $v=20 \mathrm{mV} \mathrm{s}^{-1}$, ref $\mathrm{Ag} / \mathrm{AgNO}_{3}$ ); $\mathrm{CV}$ in the oxidative part of the modified (C) GC and (D) MWCNT electrode (2 scans, $v=20 \mathrm{mV} \mathrm{s}^{-1}$, ref Ag/AgNO 3 ).

On the first scan of figure $2 \mathrm{~A}$, two irreversible overlapping cathodic peaks are observable at $E_{p}{ }^{\text {red }}$ $=-0.38 \mathrm{~V}$ and at $-0.14 \mathrm{~V}$. These peaks correspond to the catalyzed and uncatalyzed reduction of the diazonium group accompanied with aryl radical formation..$^{8,9,35}$ As expected, higher current densities, corresponding to a 30-fold increase, are observed on MWCNT electrodes, arising from high electroactive area of the MWCNT film (Figure 2B). Furthermore, a high-potential $E_{p}{ }^{\text {red }}=$ 
$+0.02 \mathrm{~V}$ also confirms the thermodynamically favorable reduction of aryldiazonium on CNT sidewalls, as already observed with different types of diazonium salts. ${ }^{23,36,37}$ On subsequent cycles, the fast reaction of aryl radicals and the formation of an

insulating polyphenylene layer at the surface of the GC electrode induce the passivation of the electrode, as confirmed by the complete disappearance of the reduction peaks. As previously observed, this passivation process decreases at MWCNT electrodes due to the high specific surface area. ${ }^{23,36,37}$ Figure $2 \mathrm{C}$ and $2 \mathrm{D}$ display $\mathrm{CV}$ performed in the anodic part of the modified GC and MWCNT electrodes after transfer in a diazonium-free $\mathrm{MeCN}$ electrolyte. Irreversible oxidations observed at $E_{p}{ }^{o x}=+0.88 \mathrm{~V}$ and $+0.76 \mathrm{~V}$ for GC and MWCNT electrodes, respectively, are associated with the oxidation of the 1,3 dithiane protecting group to generate benzaldehydemodified electrodes. ${ }^{33,34}$

\section{Preparation of the bifunctional clickable scaffolds}

Cyclopeptide scaffold $3^{38}$ was obtained via a standard SPPS (solid phase peptide synthesis) protocol, where four 6-azido-L-norleucine residues were introduced in the linear peptide sequence. ${ }^{39}$ Following cyclization in DMF, in the presence of DIPEA ( $N, N$-diisopropylamine) and PyBOP (Benzotriazole-1-yl-oxy-tris-pyrrolidino-phosphonium hexafluorophosphate) as activating agents, the Boc protecting group was removed, affording key intermediate $\mathbf{3}$ with a free lysine. Cyclic scaffold $\mathbf{1}$ was obtained upon amidation of $\mathbf{3}$ with (Boc-aminooxy)acetic acid $N$ hydroxysuccinimide ester ${ }^{40}$ followed by Boc removal in $91 \%$ yield over two steps (Figure 3). Scaffold 1 was then employed for electrode functionalization through the divergent Route A (Figure 3). To investigate the benefit of using a convergent strategy in which a pre-functionalized scaffold was immobilized via oxime ligation to the electrode (Route B, figure 3), we undertook 
the synthesis of tetra-ferrocene scaffold 5 (Figure 3). Intermediate $\mathbf{3}$ was reacted with ethynylferrocene in the presence of $\mathrm{CuSO}_{4}$, sodium ascorbate and THPTA [tris(3hydroxypropyltriazolylmethyl)amine] at room temperature. Compound 4, displaying four copies of triazole-linked ferrocenes on the upper side of the scaffold was then further functionalized on its lower side through the above described two-step protocol amidation of the free amino group to afford aminooxy-containing ferrocene scaffold $\mathbf{5}$ in a $66 \%$ overall yield (Figure $3 \mathrm{~A}$ ). The same synthetic strategy was applied to the dendrimer scaffold $6^{38}$ (Figure 3B). Tetra-azido and tetraferrocene, aminooxy-functionalized dendrimer scaffolds $\mathbf{2}$ and $\mathbf{8}$ were obtained from the common intermediate 6 in $81 \%$ and $72 \%$ overall yields, respectively (see supplementary material and figures S1-S14 for further details).

A)
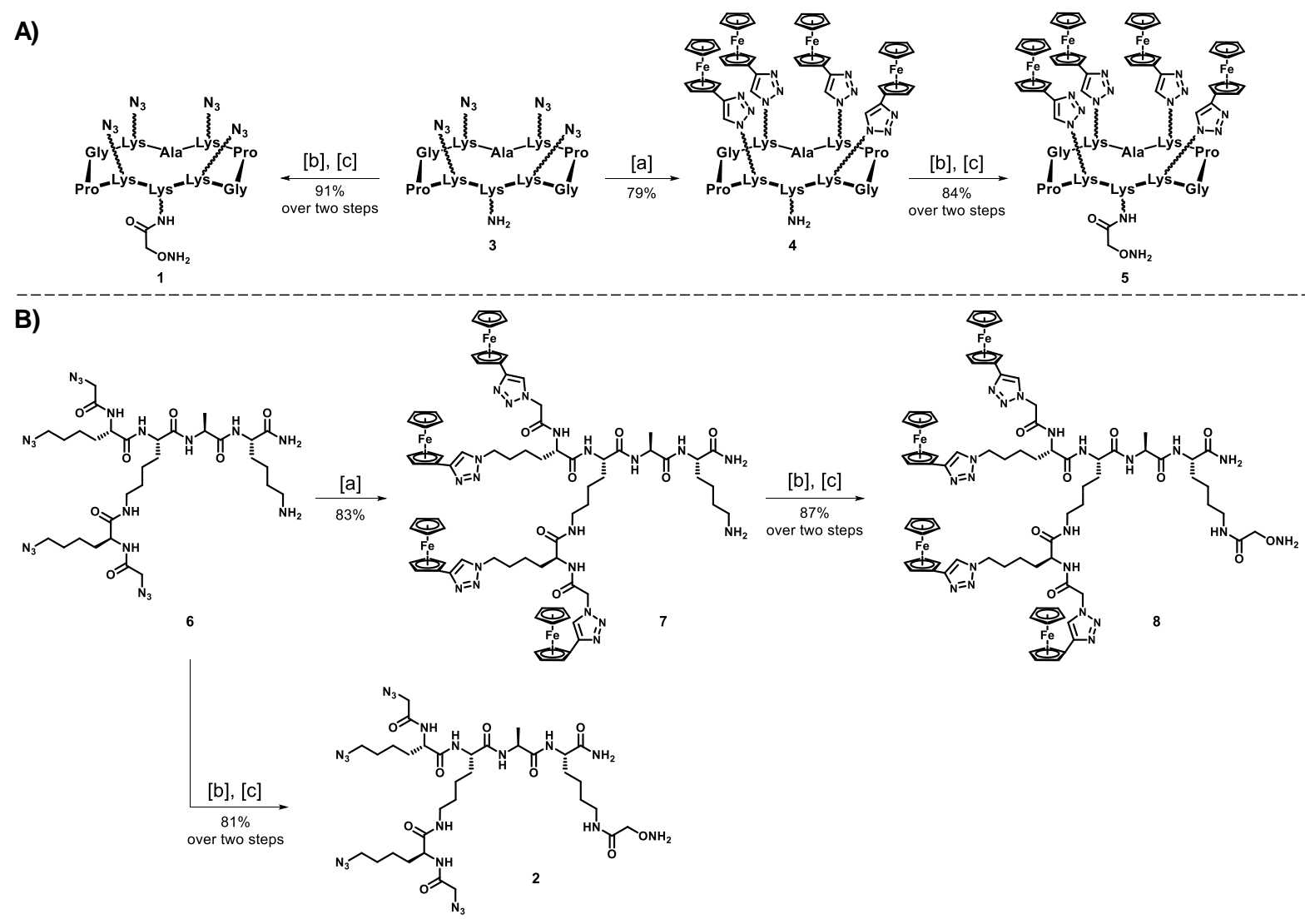
Figure 3. (A) Synthesis of tetra-azido, aminooxy-functionalized cyclic scaffold 1, and tetraferrocene, aminooxy-functionalized cyclic scaffold 5. (B) Synthesis of tetra-azido, aminooxyfunctionalized dendrimer scaffold $\mathbf{2}$, and tetra-ferrocene, aminooxy-functionalized dendrimer scaffold 8. Reagents and conditions: [a] Ethynylferrocene (6.0 eq.), $\mathrm{CuSO}_{4} \cdot 5 \mathrm{H}_{2} \mathrm{O}(\approx 2 \% \mathrm{~mol})$, THPTA (10 eq.), sodium ascorbate (27-29 eq.), DMF, PBS, 2 h, r.t.; [b] Boc-aminooxyacetic acid $N$-hydroxysuccinimide ester (1.5 eq.), DIPEA (1.5 eq.), DMF, 30 min., r.t.; [c] TFA/ $\mathrm{NH}_{2} \mathrm{OH} / \mathrm{CH}_{2} \mathrm{Cl}_{2}(50: 2: 48), 30$ min. r.t.

3. Immobilization of bifunctional clickable dendrimers and cyclopeptide on GC electrodes

GC electrodes previously-modified with the aldehyde-functionalized polyphenylene layer were employed for the immobilization of aminooxy-containing scaffolds $\mathbf{1 , 2 , 5}$ and $\mathbf{8}$ (Figure 4). 
A)

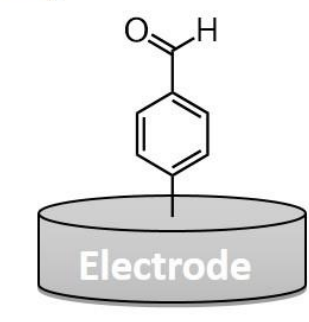

L 5

Route B
B)

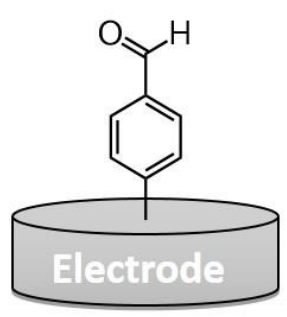

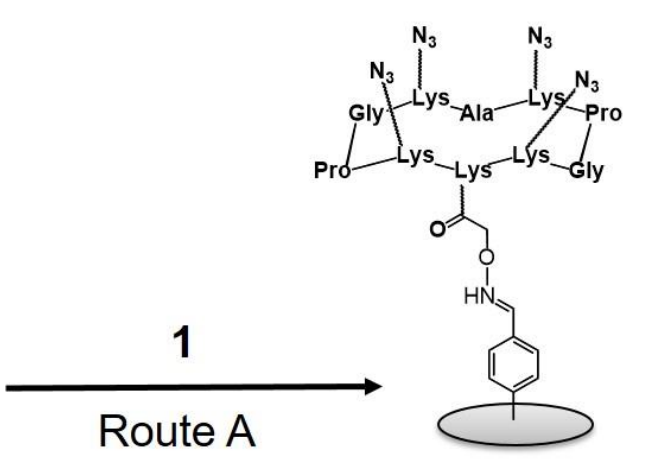

5
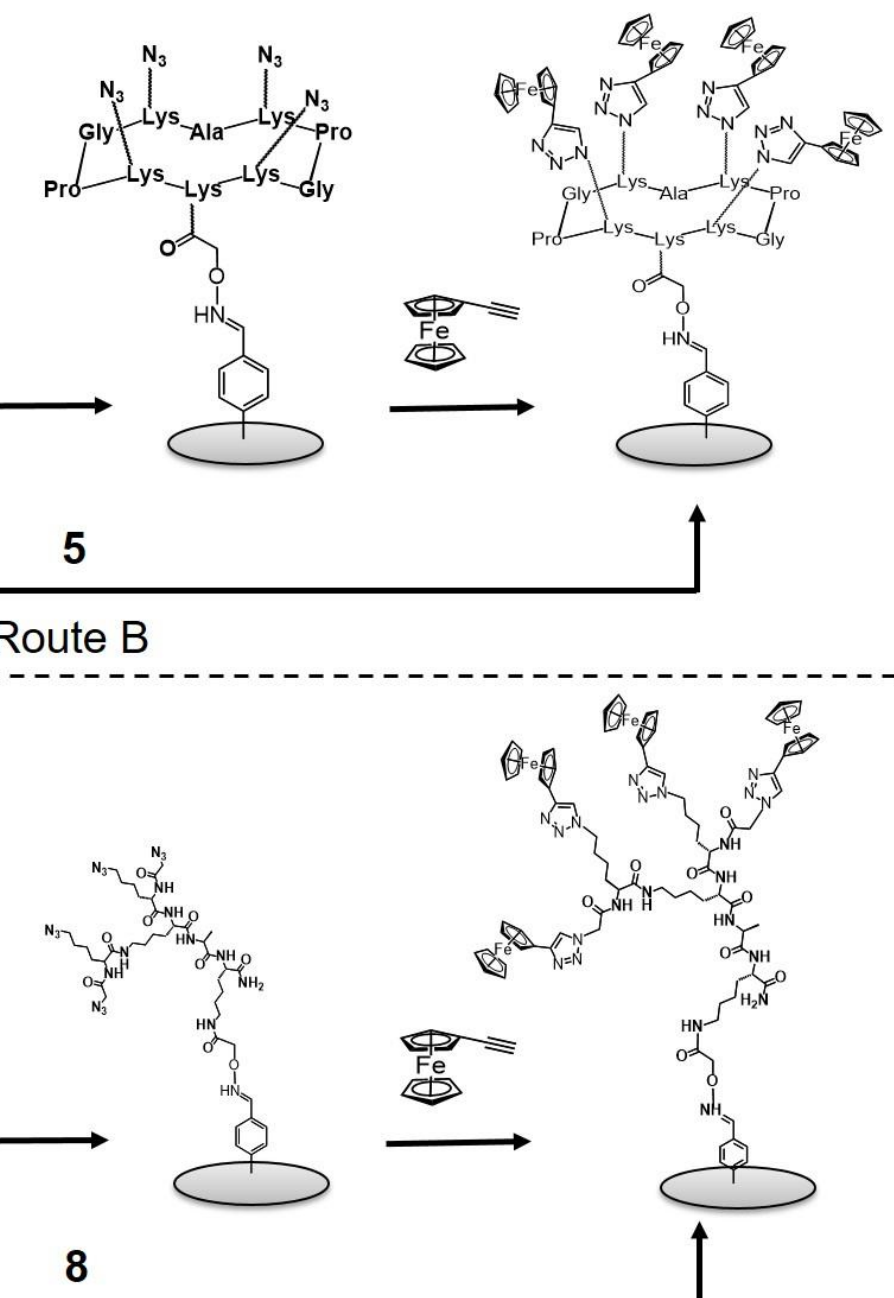

Route B

Figure 4. Functionalization of electrodes with ferrocene dendrimers (A) and cyclopeptides (B) via oxime ligation and CuAAC.

Alkyne-modified ferrocene moieties were introduced on the dendrimers either before (route B) or after (route A) the immobilization of the scaffolds on aldehyde-modified GC electrodes (Figure 4). Figure 5 displays $\mathrm{CV}$ of the modified electrode. All electrodes exhibit the typical reversible system corresponding to the $\mathrm{Fc} / \mathrm{Fc}^{+}$reversible oxidation at a standard redox potential $E_{1 / 2}=+0.37$ $\mathrm{V} v s . \mathrm{Ag} / \mathrm{AgCl}(\mathrm{KCl}$ sat). A linear dependence of both anodic and cathodic peak current intensities 
towards scan rates is in good agreement with a surface-confined redox system, characteristic of immobilized redox species.

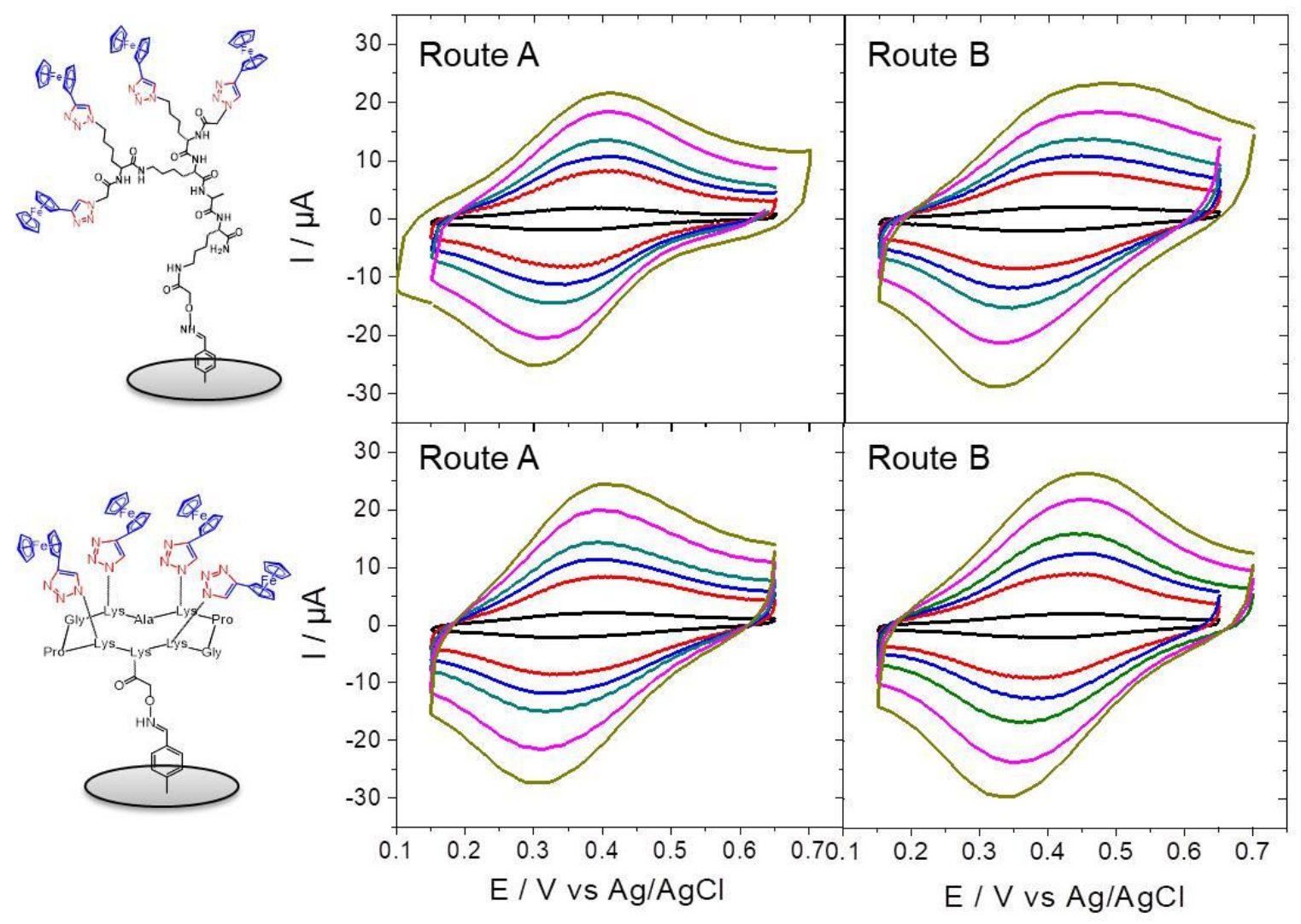

Figure 5. CV of ferrocene-modified GC electrodes according to route A and route B from figure $2\left(0.1 \mathrm{M}\right.$ sodium phosphate buffer $\left.\mathrm{pH} 7, \mathrm{v}=0.1,0.5,0.75,1,2 \mathrm{~V} \mathrm{~s}^{-1}\right)$

Table 1 displays the electrochemical characteristics of the $\mathrm{Fc} / \mathrm{Fc}^{+}$redox system for each electrode configuration. Surface coverages $\left(\Gamma_{\max }\right)$, indicator of the efficiency of the immobilization process, were measured by integration of the charge under the anodic or cathodic peaks at low scan rates giving values in the range of of 80 to $100 \mathrm{pmol} \mathrm{cm}^{-2}$ for all electrodes. This low difference in between the various Fc groups indicates the high efficiency of both the grafting of macromolecules on surfaces via oxime ligation and alkyne-ferrocene by $\mathrm{CuAAC}$. Higher values 
were obtained by immobilization of the cyclopeptide 1 followed by ferrocene functionalization (Route A). This might arise from the excellent surface accessibility of the cyclopeptide scaffold compared to the dendrimer towards ferrocene immobilization. The fact that similar amounts of ferrocene groups were grafted is indicative of the high efficiency of both the grafting of macromolecules on surfaces via oxime ligation and the grafting of alkyne-ferrocene by CuAAC. For comparison, thiol-modified cyclopeptide-ferrocene moieties were immobilized on gold electrodes, showing surfaces coverages of $60 \mathrm{pmol} \mathrm{cm}^{-2} .{ }^{25}$ Furthermore, a surface coverage of $440 \mathrm{pmol} \mathrm{cm}^{-2}$ was reported by Hapiot and colleagues using protecting silyl groups to form a quasimonolayer and before immobilization of ferrocene in a postfunctionalization step. ${ }^{35}$ Taking into account that a closely-packed ferrocene monolayer on a planar surface accounts for a surface of 450 pmol cm${ }^{-2}, 23,42,43$ this corresponds to a $20 \%$ surface occupancy in ferrocene on the planar GC electrode.

Table 1. Electrochemical characteristics of immobilized ferrocene on GC electrodes

\begin{tabular}{|l|c|c|c|}
\hline & $E_{1 / 2}\left(\mathrm{Fc} / \mathrm{Fc}^{+}\right)(\mathrm{V})$ & $\Gamma_{\max }\left(\mathrm{pmol} \mathrm{cm}_{2}^{-}\right)$ & $k_{0}\left(\mathrm{~s}^{-1}\right)$ \\
\hline $\begin{array}{l}\text { Dendrimer } \\
\text { (route A) }\end{array}$ & $0.37 \pm 0.01$ & $80 \pm 10$ & 25 \\
\hline $\begin{array}{l}\text { Dendrimer } \\
\text { (route B) }\end{array}$ & $0.37 \pm 0.01$ & $95 \pm 10$ & 10 \\
\hline $\begin{array}{l}\text { Cyclopeptide } \\
\text { (route A) }\end{array}$ & $0.37 \pm 0.01$ & $100 \pm 15$ & 30 \\
\hline $\begin{array}{l}\text { Cyclopeptide } \\
\text { (route B) }\end{array}$ & $0.37 \pm 0.01$ & $95 \pm 10$ & 20 \\
\hline
\end{tabular}

Heterogenous electron transfer rate constants $k_{0}$ between 11 and $31 \mathrm{~s}^{-1}$ were measured using the Laviron model (figure S15) ${ }^{44}$, showing no striking difference between cyclopeptides and 
dendrimers modified-electrodes. For comparison, cyclopeptide-ferrocene or oligopeptideferrocene self-assembled monolayers exhibits $k_{0}$ values between 4000 and $7000 \mathrm{~s}^{-1} \cdot{ }^{41,45}$ The twoorder of magnitude lower values obtained in this work is explained by the formation of the polyphenylene layer after electrografting of the DTBD which increase the distance between ferrocene and the electrode surface.

Immobilization of dendrimers and cyclopeptides on MWCNTs

Aldehyde-modified MWCNT electrodes were also functionalized via click-oxime by $\mathbf{5}$ and $\mathbf{8}$ according to route B from figure 3 .
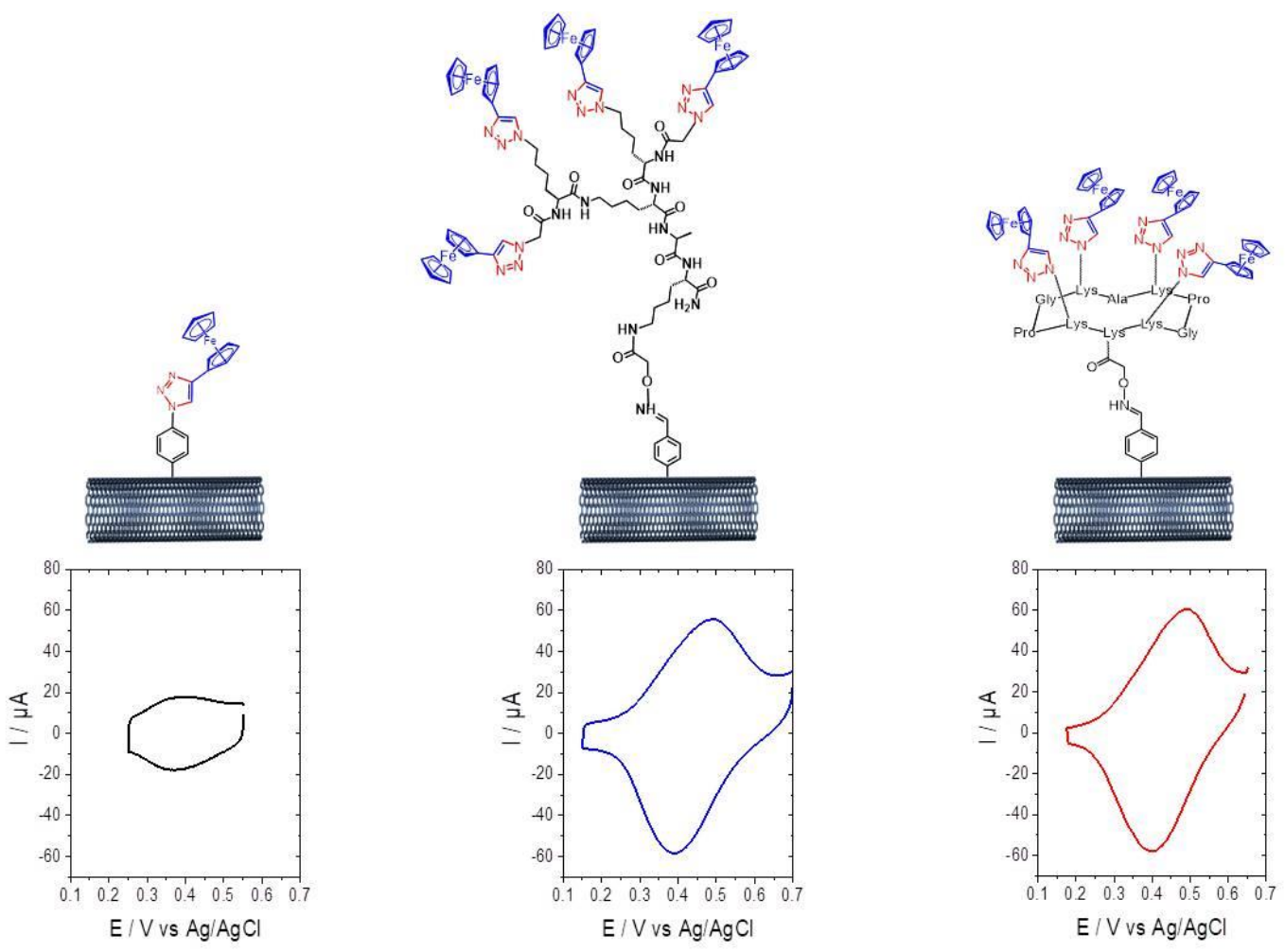

Figure 6. $\mathrm{CV}$ of ferrocene-modified MWCNT electrodes performed in $0.1 \mathrm{M}$ sodium phosphate buffer $\mathrm{pH} 7\left(\mathrm{v}=10 \mathrm{mV} \mathrm{s}^{-1}\right)$ 
Figure 6 displays CV of these electrodes accompanied with the CV of an Fc-modified MWCNT electrodes, obtained via CuAAC in between an azido-modified-MWCNT electrode and alkyne ferrocene, according to a previous study. ${ }^{21}$ Table 2 summarizes the electrochemical characteristics of the ferrocene-modified MWCNT electrodes for each configurations. $k_{0}$ values were not calculated at MWCNT electrodes since Laviron model is not suitable to describe such nanostructured and porous electrodes.

Table 2. Electrochemical characteristics of immobilized ferrocene on MWCNT electrodes

\begin{tabular}{|l|c|c|}
\hline & $E_{1 / 2}\left(\mathrm{Fc} / \mathrm{Fc}^{+}\right)(\mathrm{V})$ & $\left.\Gamma_{\max }(\mathrm{nmol} \mathrm{cm})^{-2}\right)$ \\
\hline Alkyne-Fc & $+0.37 \pm 0.01$ & $1.0 \pm 0.5$ \\
\hline Dendrimer-Fc & $+0.43 \pm 0.01$ & $44 \pm 10$ \\
\hline Cyclopeptide-Fc & $+0.43 \pm 0.01$ & $46 \pm 10$ \\
\hline
\end{tabular}

Comparing clicked dendrimers and cyclopeptide on MWCNT and GC electrodes, it is noteworthy that a 500 fold increase in the surface coverage of ferrocene moieties was obtained. This confirms both the facile modification of MWCNTs by dendrimer and cyclopeptide structures and the powerful combination of ferrocene-modified scaffolds and MWCNTs. As compared to a classic modification of azido-modified MWCNT electrodes with alkyne-ferrocene by CuAAC, we observed almost a 50-fold increase of surface coverage. This is equivalent to 100 monolayers of closely-packet ferrocene moieties, underling the synergistic effect between the mesoporous nature of the MWCNT film and the efficiency of the oxime ligation, thus allowing for an efficient approach for redox molecules immobilization at CNTs surface.

Functionalization of electrodes with alkyne-modified laccases from Trametes sp c30 
The recombinant form of LAC3, a typical fungal laccase, is produced with high yield ${ }^{46,47}$ and exhibits excellent robustness in different types of applications ${ }^{48-52}$ The fact that the LAC3 sequence is naturally poor in lysine residues $\left(\mathrm{K}_{40}\right.$ and $\left.\mathrm{K}_{71}\right)$ and that these residues are located at the surface of the amino-terminus domain (GENEBANK AAR00925.1) facilitated a strategy of introduction of specific functions at the enzyme surface allowing for LAC3 functionalization. ${ }^{52}$ In line, in the variant $\mathrm{UNIK}_{161}\left(\mathrm{~K}_{40^{-}}>\mathrm{M}, \mathrm{K}_{71-}>\mathrm{H}, \mathrm{R}_{161^{-}}>\mathrm{K}\right)$ a single functionalized amino group is located near the T1 copper center. ${ }^{53}$ Thereby, LAC3 and $\mathrm{UNK}_{161}$ are offering immobilization possibilities in two opposite orientations relative to the $\mathrm{T} 1$ center for the same enzyme. ${ }^{21,52}$ Here, alkyne-modified LAC3 enzymes were covalently attached to dendrimer and cyclopeptidemodified MWCNTs.

Figure 7 displays $\mathrm{CV}$ performed under $\mathrm{Ar}$ and $\mathrm{O}_{2}$ in the presence of ABTS, a commonlyemployed redox partner of LAC3. 

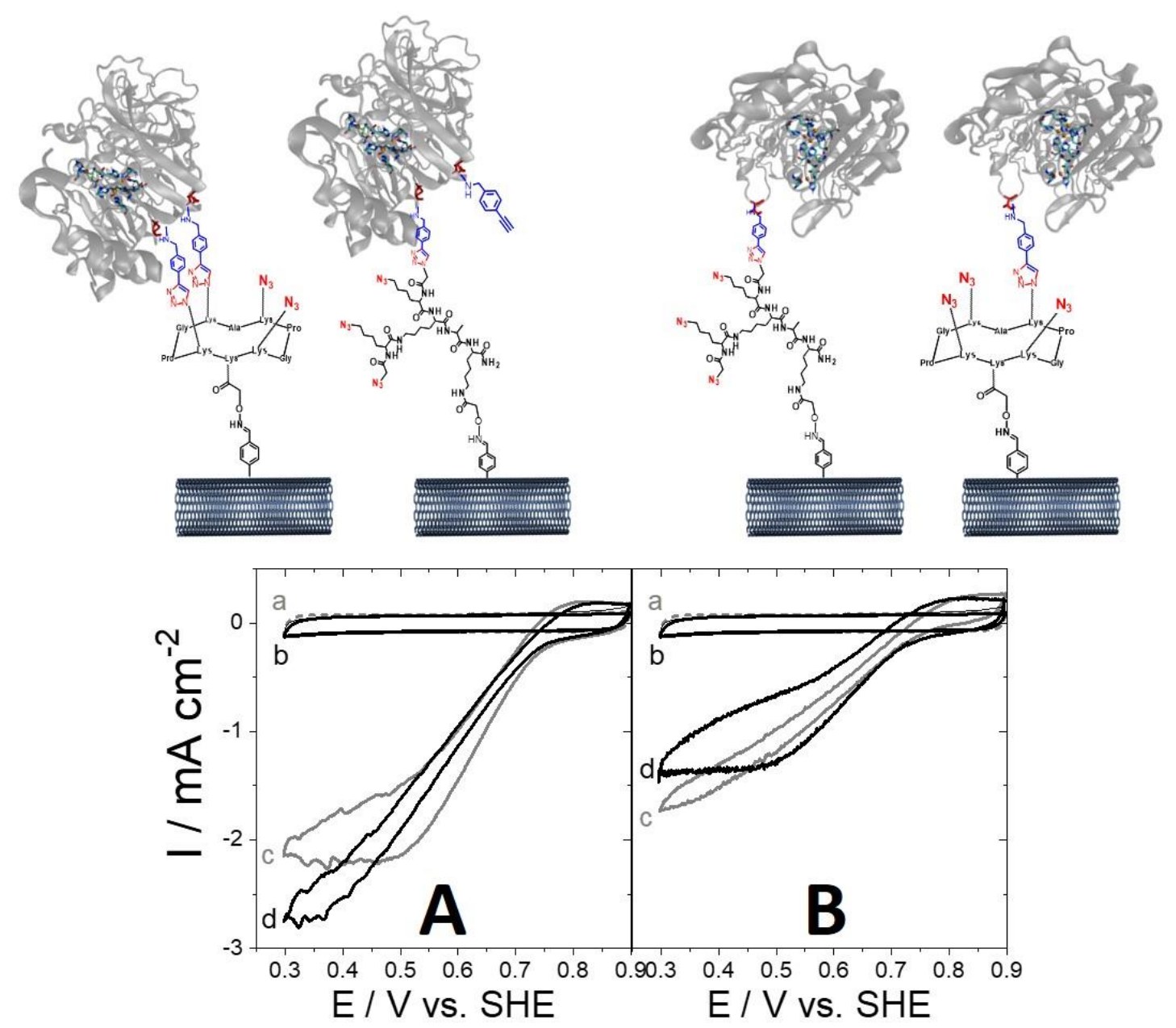

Figure 7. (A) CV of MWCNT electrodes after immobilization of alkyne-modified LAC3 on (grayline) cyclopeptide-modified and (black line) dendrimers-modified MWCNTs and (B) CV of MWCNT electrodes after immobilization of alkyne-modified UNIK 161 on (gray-line) cyclopeptide-modified and (black line) dendrimers-modified MWCNTs (a, b) under Ar, and (c, d) under $\mathrm{O}_{2}$ after the addition of $10 \mathrm{mM}$ ABTS $\left(0.05 \mathrm{~mol} \mathrm{~L}^{-1}\right.$ acetate buffer solution $\mathrm{pH} 5, v=10 \mathrm{mV}$ $\left.\mathrm{s}^{-1}\right)$.

The irreversible reduction wave, observed at onset potentials of $+0.75 \mathrm{~V} v s$. SHE, corresponds to the electrocatalytic reduction of $\mathrm{O}_{2}$ by immobilized LAC3, mediated by ABTS. Similar electrocatalytic current densities between -2 and $-3 \mathrm{~mA} \mathrm{~cm}^{-2}$ (Figure 7A) confirm that both 
cyclopeptide and dendrimer scaffolds have the same ability to graft alkyne-modified enzymes, as already observed for ferrocene moieties. On the other hand, lower current densities around -1.5 $\mathrm{mA} \mathrm{cm}{ }^{-2}$ were observed for UNIK161 (figure 7B), as UNIK161 possesses one single alkynemodified residue while the native modified-LAC3 possesses two. Furthermore, taking into account that orientation of UNIK161 implies that the T1 site points towards the electrode surface, access of ABTS to the T1 substrate binding site might be hindered. The result fits well with current densities observed in the case of alkyne-modified LAC3 enzymes immobilized on azide-modified MWCNTs. ${ }^{21}$ Unlike ferrocene immobilization, this demonstrates that the addition of a cyclopeptide or dendrimer scaffold do not increase the enzymatic surface coverage, as expected from the large size of LAC3 enzymes (by almost ten folds compared to cyclopeptides) as compared to both scaffolds and ferrocene moieties. Direct electron transfer (DET) properties of these modified MWCNTs were also investigated in the case of immobilized LAC3. Figure 8 displays $\mathrm{CV}$ performed under $\mathrm{O}_{2}$ without $\mathrm{ABTS}$. 

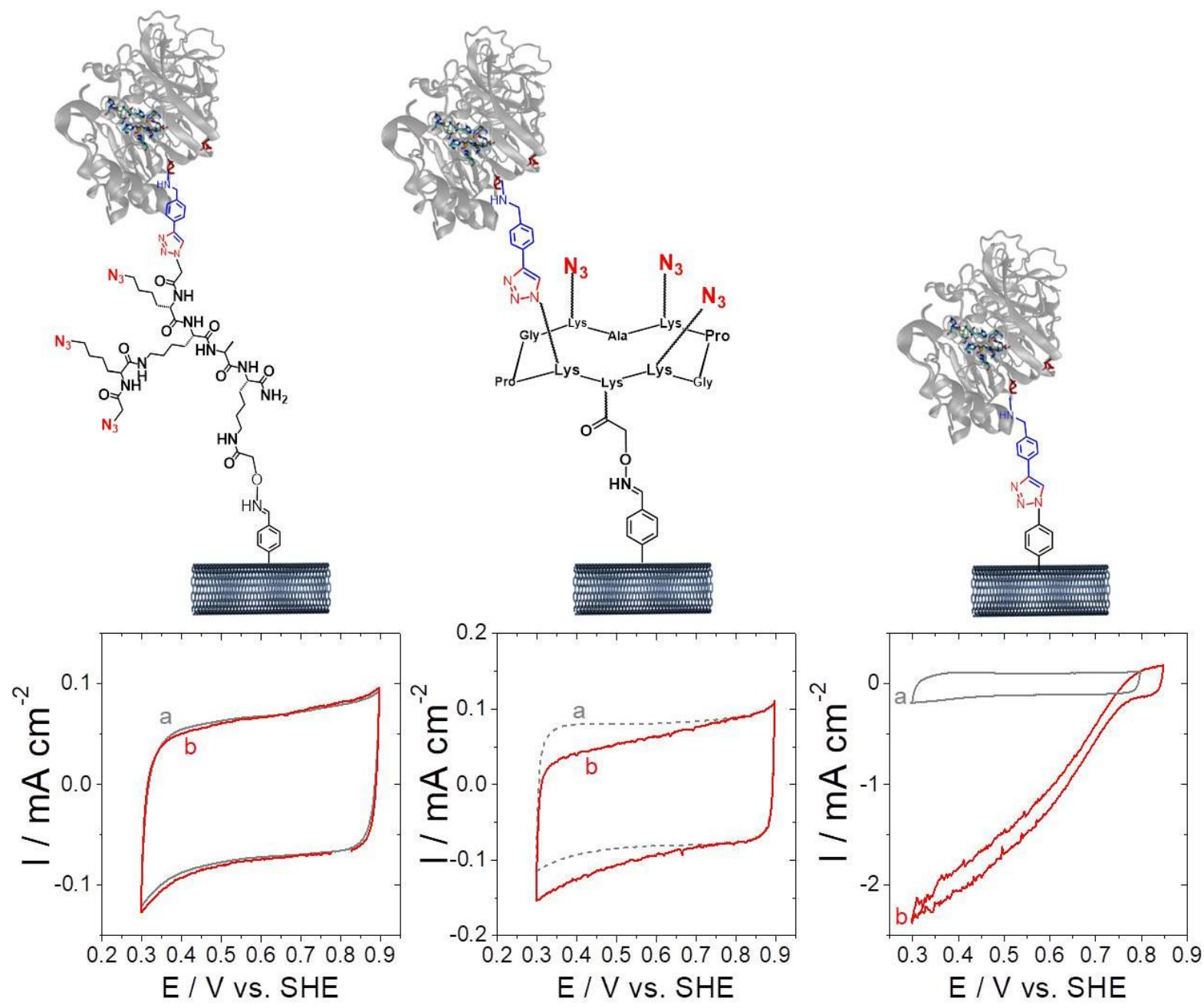

Figure 8. CV of MWCNT electrodes after immobilization of alkyne-modified LAC3 on dendrimer-modified, cyclopeptide-modified and 4-azidobenzene diazonium-modified MWCNT

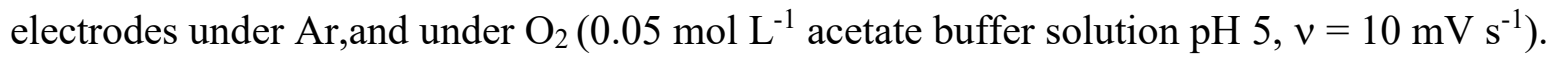

Cyclopeptide- and dendrimer-modified MWCNT electrodes were compared to the previouslymodified azidophenyl-modified MWCNT electrodes. Low current densities were observed towards direct $\mathrm{O}_{2}$ reduction at 10 and $50 \mu \mathrm{A} \mathrm{cm}{ }^{-2}$ for the LAC3-dendrimer and cyclopeptide respective systems, respectively. On the contrary, when LAC3 is directly clicked-on on azidomodified-MWCNT electrodes, an efficient DET is observed with maximum current densities of - 
$2.1 \mathrm{~mA} \mathrm{~cm}^{-2}$ and half-wave potentials of $+0.65 \mathrm{~V} v \mathrm{~s}$. SHE, closed to the redox potential of the enzyme, $0.68 \mathrm{~V}$ vs. SHE. ${ }^{21,54}$ These results demonstrate that the designed scaffolds are highly efficient at immobilizing enzymes. However, distances between the electrode surface and the enzyme active redox centers are increased by 20 to $25 \mathrm{~A}$, which corresponds to the approximative length of the scaffolds ${ }^{41}$ but also the upper limit for detection of electron tunneling in proteins by bioelectrochemistry. ${ }^{55}$ Accordingly, when enzymes are directly immobilized on a thin electrografted layer, DET is observed as well as electrocatalytic wave towards $\mathrm{O}_{2}$ reduction at the redox potential of the enzyme multicopper active site.

\section{Conclusion}

This work describes a novel way of immobilization of redox molecules on surface by using cyclopeptide and dendrimer scaffolds immobilized by oxime ligation. Using its high flexibility in accommodating different clickable functions, the combination of both MWCNT surfaces and modified dendrimers or cyclopeptides allow the access to high surface coverages of ferrocene in the order of $50 \mathrm{nmol} \mathrm{cm}$, almost one order of magnitude higher compared to a simple click reactions and several order of magnitude for immobilization on planar surfaces. Furthermore, these electrodes allow the immobilization of functionalized active metalloenzymes such as laccases. Comparing the immobilization of ferrocene and redox enzymes, we can conclude that dendrimers and cyclopeptide are highly efficient in the immobilization of small redox molecules on surfaces, owing to these highly-branched scaffolds at nanostructured electrodes. In addition, these scaffolds do not provide any significant advantage in terms of surface coverage in the immobilization of macromolecules such as laccases, andare detrimental to the direct wiring of 
these enzymes by increasing tunneling distances between the electrode surface and the enzyme's redox centers and that despite of a proper control of the orientation of enzymes relative to the surfaces. However, these surfaces can still be envisioned for building laccase-based sensors where DET hampers the sensing of phenolic substrates. Thanks to the high surface coverage brought by these novel scaffolds, we will further investigate their use for surface functionalization strategies with molecular catalysts and smaller enzymes involved in sensing or energy applications.

\section{AUTHOR INFORMATION}

\section{Corresponding Author}

alan.le-goff@univ-grenoble-alpes.fr, Olivier.renaudet@univ-grenoble-alpes.fr, Thierry.tron@univ-amu.fr

\section{Author Contributions}

The manuscript was written through contributions of all authors. All authors have given approval to the final version of the manuscript.

\section{ACKNOWLEDGMENT}

This work was supported by the Labex ARCANE ((ANR-11-LABX-0003-01), the Graduate School on Chemistry, Biology and Health of Univ Grenoble Alpes CBH-EUR-GS (ANR-17EURE-0003) and ANR Multiplet (ANR-15- CE07-0021-01). The authors wish to acknowledge the platform Chimie NanoBio ICMG FR 2607 (PCN-ICMG). This work was also supported by the Ministère de l'Environnement, de l'Energie et de la Mer. We thank Yolande Charmasson, Elise Courvoisier-Dezord and the plateforme AVB: Analyse \& Valorisation de la Biodiversité at AMU for technical support in the production of the recombinant enzyme. 


\section{References}

(1) Le Goff, A.; Holzinger, M. Molecular Engineering of the Bio/Nano-Interface for Enzymatic Electrocatalysis in Fuel Cells. Sustain. Energy Fuels 2018, 2 (12), 2555-2566.

https://doi.org/10.1039/c8se00374b.

(2) Rasmussen, M.; Abdellaoui, S.; Minteer, S. D. Enzymatic Biofuel Cells: 30 Years of Critical Advancements. Biosens. Bioelectron. 2016, 76, 91-102. https://doi.org/10.1016/j.bios.2015.06.029.

(3) Xiao, X.; Xia, H.; Wu, R.; Bai, L.; Yan, L.; Magner, E.; Cosnier, S.; Lojou, E.; Zhu, Z.; Liu, A. Tackling the Challenges of Enzymatic (Bio)Fuel Cells. Chem. Rev. 2019, 119 (16), 9509-9558. https://doi.org/10.1021/acs.chemrev.9b00115.

(4) Mano, N. Recent Advances in High Surface Area Electrodes for Bioelectrochemical Applications. Curr. Opin. Electrochem. 2020, 19, 8-13. https://doi.org/10.1016/j.coelec.2019.09.003.

(5) García-Molina, G.; Pita, M.; De Lacey, A. L. Novel Bioelectrocatalytic Strategies Based on Immobilized Redox Metalloenzymes on Tailored Electrodes. In Novel Catalyst Materials for Bioelectrochemical Systems: Fundamentals and Applications; ACS Symposium Series; American Chemical Society, 2020; Vol. 1342, pp 207-229. https://doi.org/10.1021/bk-2020-1342.ch010.

(6) Le Goff, A.; Artero, V.; Jousselme, B.; Tran, P. D.; Guillet, N.; Metaye, R.; Fihri, A.; Palacin, S.; Fontecave, M. From Hydrogenases to Noble Metal-Free Catalytic Nanomaterials for $\mathrm{H} 2$ Production and Uptake. Science 2009, 326 (5958), 1384-1387.

(7) Gentil, S.; Lalaoui, N.; Dutta, A.; Nedellec, Y.; Cosnier, S.; Shaw, W. J.; Artero, V.; Le Goff, A. Carbon-Nanotube-Supported Bio-Inspired Nickel Catalyst and Its Integration in Hybrid Hydrogen/Air Fuel Cells. Angew. Chem. Int. Ed. 2017, 56 (7), 1845-1849. https://doi.org/10.1002/anie.201611532.

(8) Delamar, M.; Hitmi, R.; Pinson, J.; Saveant, J. M. Covalent Modification of Carbon Surfaces by Grafting of Functionalized Aryl Radicals Produced from Electrochemical Reduction of Diazonium Salts. J. Am. Chem. Soc. 1992, 114 (14), 5883-5884. https://doi.org/10.1021/ja00040a074.

(9) Allongue, P.; Delamar, M.; Desbat, B.; Fagebaume, O.; Hitmi, R.; Pinson, J.; Savéant, J.-M. Covalent Modification of Carbon Surfaces by Aryl Radicals Generated from the Electrochemical Reduction of Diazonium Salts. J. Am. Chem. Soc. 1997, 119 (1), 201-207. https://doi.org/10.1021/ja963354s.

(10) Bélanger, D.; Pinson, J. Electrografting: A Powerful Method for Surface Modification. Chem. Soc. Rev. 2011, 40 (7), 3995-4048. https://doi.org/10.1039/C0CS00149J.

(11) Jones, S. M.; Solomon, E. I. Electron Transfer and Reaction Mechanism of Laccases. Cell. Mol. Life Sci. 2015, 72 (5), 869-883. https://doi.org/10.1007/s00018-014-1826-6.

(12) Giardina, P.; Faraco, V.; Pezzella, C.; Piscitelli, A.; Vanhulle, S.; Sannia, G. Laccases: A Never-Ending Story. Cell. Mol. Life Sci. 2010, 67 (3), 369-385. https://doi.org/10.1007/s00018-009-0169-1.

(13) Le Goff, A.; Holzinger, M.; Cosnier, S. Recent Progress in Oxygen-Reducing Laccase Biocathodes for Enzymatic Biofuel Cells. Cell. Mol. Life Sci. 2015, 72 (5), 941-952. https://doi.org/10.1007/s00018-014-1828-4.

(14) Mano, N.; de Poulpiquet, A. O2 Reduction in Enzymatic Biofuel Cells. Chem. Rev. 2017, 118 (5), 2392-2468. https://doi.org/10.1021/acs.chemrev.7b00220.

(15) Blanford, C. F.; Heath, R. S.; Armstrong, F. A. A Stable Electrode for High-Potential, Electrocatalytic $\mathrm{O} 2$ Reduction Based on Rational Attachment of a Blue Copper Oxidase to a Graphite Surface. Chem. Commun. 2007, No. 17, 1710. https://doi.org/10.1039/b703114a. 
(16) Blanford, C. F.; Foster, C. E.; Heath, R. S.; Armstrong, F. A. Efficient Electrocatalytic Oxygen Reduction by the 'Blue' Copper Oxidase, Laccase, Directly Attached to Chemically Modified Carbons. Faraday Discuss. 2008, 140 (0), 319-335. https://doi.org/10.1039/B808939F.

(17) Alonso-Lomillo, M. A.; Rüdiger, O.; Maroto-Valiente, A.; Velez, M.; Rodríguez-Ramos, I.; Muñoz, F. J.; Fernández, V. M.; De Lacey, A. L. Hydrogenase-Coated Carbon Nanotubes for Efficient H2 Oxidation. Nano Lett. 2007, 7 (6), 1603-1608. https://doi.org/10.1021/nl070519u.

(18) Tasca, F.; Harreither, W.; Ludwig, R.; Gooding, J. J.; Gorton, L. Cellobiose Dehydrogenase Aryl Diazonium Modified Single Walled Carbon Nanotubes: Enhanced Direct Electron Transfer through a Positively Charged Surface. Anal. Chem. 2011, 83 (8), 3042-3049.

https://doi.org/10.1021/ac103250b.

(19) Baffert, C.; Sybirna, K.; Ezanno, P.; Lautier, T.; Hajj, V.; Meynial-Salles, I.; Soucaille, P.; Bottin, H.; Léger, C. Covalent Attachment of FeFe Hydrogenases to Carbon Electrodes for Direct Electron Transfer. Anal. Chem. 2012, 84 (18), 7999-8005. https://doi.org/10.1021/ac301812s.

(20) Gutiérrez-Sánchez, C.; Jia, W.; Beyl, Y.; Pita, M.; Schuhmann, W.; De Lacey, A. L.; Stoica, L. Enhanced Direct Electron Transfer between Laccase and Hierarchical Carbon Microfibers/Carbon Nanotubes Composite Electrodes. Comparison of Three Enzyme Immobilization Methods. Electrochimica Acta 2012, 82, 218-223. https://doi.org/10.1016/j.electacta.2011.12.134.

(21) Gentil, S.; Rousselot-Pailley, P.; Sancho, F.; Robert, V.; Mekmouche, Y.; Guallar, V.; Tron, T.; Goff, A. L. Efficiency of Site-Specific Clicked Laccase-Carbon Nanotubes Biocathodes towards $\mathrm{O} 2$ Reduction. Chem. - Eur. J. 2020, 26 (21), 4798-4804. https://doi.org/10.1002/chem.201905234.

(22) Bahr, J. L.; Tour, J. M. Highly Functionalized Carbon Nanotubes Using in Situ Generated Diazonium Compounds. Chem. Mater. 2001, 3823-3824.

(23) Le Goff, A.; Moggia, F.; Debou, N.; Jegou, P.; Artero, V.; Fontecave, M.; Jousselme, B.; Palacin, S. Facile and Tunable Functionalization of Carbon Nanotube Electrodes with Ferrocene by Covalent Coupling and $\pi$-Stacking Interactions and Their Relevance to Glucose Bio-Sensing. J. Electroanal. Chem. 2010, 57-63.

(24) Boas, U.; Christensen, J. B. D.; Christensen, J. B.; Heegaard, P. M. H. Dendrimers in Medicine and Biotechnology: New Molecular Tools; Royal Society of Chemistry, 2006.

(25) Borisova, B.; Ramos, J.; Díez, P.; Sánchez, A.; Parrado, C.; Araque, E.; Villalonga, R.; Pingarrón, J. M. A Layer-by-Layer Biosensing Architecture Based on Polyamidoamine Dendrimer and Carboxymethylcellulose-Modified Graphene Oxide. Electroanalysis 2015, DOI: 10.1002/elan.201500098. https://doi.org/10.1002/elan.201500098.

(26) Araque, E.; Villalonga, R.; Gamella, M.; Martínez-Ruiz, P.; Reviejo, J.; Pingarrón, J. M. Crumpled Reduced Graphene Oxide-Polyamidoamine Dendrimer Hybrid Nanoparticles for the Preparation of an Electrochemical Biosensor. J. Mater. Chem. B 2013, 1 (17), 2289-2296. https://doi.org/10.1039/C3TB20078G.

(27) Vögtle, F.; Richardt, G.; Werner, N. Dendrimer Chemistry: Concepts, Syntheses, Properties, Applications; John Wiley \& Sons, 2009.

(28) Thomas, B.; Fiore, M.; Chand Daskhan, G.; Spinelli, N.; Renaudet, O. A Multi-Ligation Strategy for the Synthesis of Heterofunctionalized Glycosylated Scaffolds. Chem. Commun. 2015, 51 (25), 5436-5439. https://doi.org/10.1039/C4CC05451B.

(29) Campidelli, S.; Sooambar, C.; Diz, E. L.; Ehli, C.; Guldi, D. M.; Prato, M. Dendrimer-Functionalized Single-Wall Carbon Nanotubes: Synthesis, Characterization, and Photoinduced Electron Transfer. 2006, 12544-12552.

(30) Palacin, T.; Khanh, H. L.; Jousselme, B.; Jegou, P.; Filoramo, A.; Ehli, C.; Guldi, D. M.; Campidelli, S. Efficient Functionalization of Carbon Nanotubes with Porphyrin Dendrons via Click Chemistry. 2009, 15394-15402. 
(31) Collins, J.; Xiao, Z.; Müllner, M.; Connal, L. A. The Emergence of Oxime Click Chemistry and Its Utility in Polymer Science. Polym. Chem. 2016, 7 (23), 3812-3826.

https://doi.org/10.1039/C6PY00635C.

(32) Ulrich, S.; Boturyn, D.; Marra, A.; Renaudet, O.; Dumy, P. Oxime Ligation: A Chemoselective ClickType Reaction for Accessing Multifunctional Biomolecular Constructs. Chem. - Eur. J. 2014, 20 (1), 34-41. https://doi.org/10.1002/chem.201302426.

(33) Haque, A.-M. J.; Kwon, S.-R.; Park, H.; Kim, T.-H.; Oh, Y.-S.; Choi, S.-Y.; Hong, J.-D.; Kim, K. Use of 1,3-Dithiane Combined with Aryldiazonium Cation for Immobilization of Biomolecules Based on Electrochemical Addressing. Chem. Commun. 2009, No. 32, 4865-4867.

https://doi.org/10.1039/B909244G.

(34) Haque, A.-M. J.; Kim, K. Aldehyde-Functionalized Benzenediazonium Cation for Multiprobe Immobilization on Microelectrode Array Surfaces. Langmuir 2011, 27 (3), 882-886. https://doi.org/10.1021/la104270b.

(35) Lee, L.; Brooksby, P. A.; Hapiot, P.; Downard, A. J. Electrografting of 4-Nitrobenzenediazonium lon at Carbon Electrodes: Catalyzed and Uncatalyzed Reduction Processes. Langmuir 2016, 32 (2), 468-476. https://doi.org/10.1021/acs.langmuir.5b03233.

(36) Lalaoui, N.; Holzinger, M.; Le Goff, A.; Cosnier, S. Diazonium Functionalisation of Carbon Nanotubes for Specific Orientation of Multicopper Oxidases: Controlling Electron Entry Points and Oxygen Diffusion to the Enzyme. Chem. - Eur. J. 2016, 22 (30), 10494-10500.

https://doi.org/10.1002/chem.201601377.

(37) Gentil, S.; Che Mansor, S. M.; Jamet, H.; Cosnier, S.; Cavazza, C.; Le Goff, A. Oriented Immobilization of [NiFeSe] Hydrogenases on Covalently and Noncovalently Functionalized Carbon Nanotubes for H2/Air Enzymatic Fuel Cells. ACS Catal. 2018, 3957-3964. https://doi.org/10.1021/acscatal.8b00708.

(38) Pifferi, C.; Goyard, D.; Gillon, E.; Imberty, A.; Renaudet, O. Synthesis of Mannosylated Glycodendrimers and Evaluation against BC2L-A Lectin from Burkholderia Cenocepacia. ChemPlusChem 2017, 82 (3), 390-398. https://doi.org/10.1002/cplu.201600569.

(39) Bossu, I.; Berthet, N.; Dumy, P.; Renaudet, O. Synthesis of Glycocyclopeptides by Click Chemistry and Inhibition Assays with Lectins. J. Carbohydr. Chem. 2011, 30 (7-9), 458-468. https://doi.org/10.1080/07328303.2011.590260.

(40) Foillard, S.; Rasmussen, M. O.; Razkin, J.; Boturyn, D.; Dumy, P. 1-Ethoxyethylidene, a New Group for the Stepwise SPPS of Aminooxyacetic Acid Containing Peptides. J. Org. Chem. 2008, 73 (3), 983-991. https://doi.org/10.1021/jo701628k.

(41) Devillers, C. H.; Boturyn, D.; Bucher, C.; Dumy, P.; Labbé, P.; Moutet, J.-C.; Royal, G.; Saint-Aman, E. Redox-Active Biomolecular Architectures and Self-Assembled Monolayers Based on a Cyclodecapeptide Regioselectively Addressable Functional Template. Langmuir 2006, 22 (19), 8134-8143. https://doi.org/10.1021/la060491m.

(42) Lee, L. Y. S.; Sutherland, T. C.; Rucareanu, S.; Lennox, R. B. Ferrocenylalkylthiolates as a Probe of Heterogeneity in Binary Self-Assembled Monolayers on Gold. Langmuir 2006, 22 (9), 4438-4444. https://doi.org/10.1021/la053317r.

(43) Chidsey, C. E. D.; Bertozzi, C. R.; Putvinski, T. M.; Mujsce, A. M. Coadsorption of FerroceneTerminated and Unsubstituted Alkanethiols on Gold: Electroactive Self-Assembled Monolayers. J. Am. Chem. Soc. 1990, 112 (11), 4301-4306. https://doi.org/10.1021/ja00167a028.

(44) Laviron, E. General Expression of the Linear Potential Sweep Voltammogram in the Case of Diffusionless Electrochemical Systems. J. Electroanal. Chem. Interfacial Electrochem. 1979, 101 (1), 19-28. https://doi.org/10.1016/S0022-0728(79)80075-3. 
(45) Bediako-Amoa, I.; Sutherland, T. C.; Li, C.-Z.; Silerova, R.; Kraatz, H.-B. Electrochemical and Surface Study of Ferrocenoyl Oligopeptides. J. Phys. Chem. B 2004, 108 (2), 704-714. https://doi.org/10.1021/jp0368785.

(46) Klonowska, A.; Gaudin, C.; Asso, M.; Fournel, A.; Réglier, M.; Tron, T. LAC3, a New Low Redox Potential Laccase from Trametes Sp. Strain C30 Obtained as a Recombinant Protein in Yeast. Enzyme Microb. Technol. 2005, 36 (1), 34-41. https://doi.org/10.1016/j.enzmictec.2004.03.022.

(47) Mekmouche, Y.; Zhou, S.; Cusano, A. M.; Record, E.; Lomascolo, A.; Robert, V.; Simaan, A. J.; Rousselot-Pailley, P.; Ullah, S.; Chaspoul, F.; Tron, T. Gram-Scale Production of a Basidiomycetous Laccase in Aspergillus Niger. J. Biosci. Bioeng. 2014, 117 (1), 25-27.

https://doi.org/10.1016/j.jbiosc.2013.06.013.

(48) Mekmouche, Y.; Schneider, L.; Rousselot-Pailley, P.; Faure, B.; Simaan, A. J.; Bochot, C.; Reglier, M.; Tron, T. Laccases as Palladium Oxidases. Chem. Sci. 2015, 6 (2), 1247-1251. https://doi.org/10.1039/c4sc02564d.

(49) Lazarides, T.; Sazanovich, I. V.; Simaan, A. J.; Kafentzi, M. C.; Delor, M.; Mekmouche, Y.; Faure, B.; Réglier, M.; Weinstein, J. A.; Coutsolelos, A. G.; Tron, T. Visible Light-Driven 02 Reduction by a Porphyrin-Laccase System. J. Am. Chem. Soc. 2013, 135 (8), 3095-3103. https://doi.org/10.1021/ja309969s.

(50) Schneider, L.; Mekmouche, Y.; Rousselot-Pailley, P.; Simaan, A. J.; Robert, V.; Reglier, M.; Aukauloo, A.; Tron, T. Visible-Light-Driven Oxidation of Organic Substrates with Dioxygen Mediated by a [Ru(Bpy)(3)](2+)/Laccase System. Chemsuschem 2015, 8 (18), 3048-3051. https://doi.org/10.1002/cssc.201500602.

(51) Simaan, A. J.; Mekmouche, Y.; Herrero, C.; Moreno, P.; Aukauloo, A.; Delaire, J. A.; Réglier, M.; Tron, T. Photoinduced Multielectron Transfer to a Multicopper Oxidase Resulting in Dioxygen Reduction into Water. Chem. - Eur. J. 2011, 17 (42), 11743-11746. https://doi.org/10.1002/chem.201101282.

(52) Lalaoui, N.; Rousselot-Pailley, P.; Robert, V.; Mekmouche, Y.; Villalonga, R.; Holzinger, M.; Cosnier, S.; Tron, T.; Le Goff, A. Direct Electron Transfer between a Site-Specific Pyrene-Modified Laccase and Carbon Nanotube/Gold Nanoparticle Supramolecular Assemblies for Bioelectrocatalytic Dioxygen Reduction. ACS Catal. 2016, 6, 1894-1900. https://doi.org/10.1021/acscatal.5b02442.

(53) Robert, V.; Monza, E.; Tarrago, L.; Sancho, F.; De Falco, A.; Schneider, L.; Npetgat Ngoutane, E.; Mekmouche, Y.; Pailley, P. R.; Simaan, A. J.; Guallar, V.; Tron, T. Probing the Surface of a Laccase for Clues towards the Design of Chemo-Enzymatic Catalysts. ChemPlusChem 2017, 82 (4), 607614. https://doi.org/10.1002/cplu.201700030.

(54) Balland, V.; Hureau, C.; Cusano, A. M.; Liu, Y.; Tron, T.; Limoges, B. Oriented Immobilization of a Fully Active Monolayer of Histidine-Tagged Recombinant Laccase on Modified Gold Electrodes. Chem. - Eur. J. 2008, 14 (24), 7186-7192. https://doi.org/10.1002/chem.200800368.

(55) Winkler, J. R.; Gray, H. B. Long-Range Electron Tunneling. J. Am. Chem. Soc. 2014, 136 (8), 29302939. https://doi.org/10.1021/ja500215j. 